\title{
Indeks Gonadosomatik dan Struktur Histologis Gonad Ikan Uceng (Nemacheilus fasciatus, Valenciennes in Cuvier and Valenciennes, 1846)
}

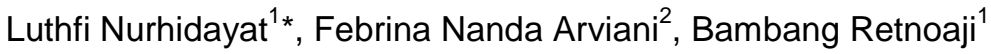 \\ ${ }^{1}$ Laboratorium Struktur Perkembangan Hewan, Fakultas Biologi, Universitas Gadjah Mada \\ ${ }^{2}$ Program Sarjana, , Fakultas Biologi, Universitas Gadjah Mada \\ *corresponding author: luthfibio@ugm.ac.id
}

\begin{abstract}
Barred loach (Nemacheilus fasciatus), locally welknown as uceng, is wild native fish of Indonesia that live in freshwater river. It is very common that people consume the fish for it high protein content. High demand of this fish causes high exploitation in nature population. The high intensity of fish exploitation will induce declining population of the fish and leading to extinction. Uceng fish cultivation is one alternative to solve the treat. The purpose of this research is to examine the Gonadosomatic Index (GSI) and gonad histological structure of male and female uceng fish (Nemacheilus fasciatus) on the period of immature and mature. Fish were captured on May and August 2015 from Kayangan river, Pandawaharjo, Kulonprogo. Fish were dissected, weighted and the gonads were measured for gonadosomatic index. Moreover, gonads were fixed in NBF 5\% for histological preparation by paraffin method and which then were stained by Hematoxylin-Eosin. The results were analyzed for both qualitatively and quantitatively. Qualitative analysis was conducted for gonad histological structure of male and female fish, while quantitative analysis was for Gonadosomatic Index (GSI) of fish, respectively. The result showed that there were differences on the gonadosomatic index of males and females fish, the histological structure of ovarian follicle and the composition of the spermatogenic cells of immature gonads and mature gonads of the fish, respectively. It can be concluded that Barred loach is still possible to do spawning in the dry season, but the results will not be satisfactory.
\end{abstract}

Key Words : Barred loach (Nemacheilus fasciatus), Gonadosomatic Index, gonad

\begin{abstract}
Abstrak
Ikan uceng merupakan ikan yang terbiasa hidup liar di sungai. Ikan uceng termasuk ikan dengan nilai ekonomi yang tinggi dan masyarakat Indonesia biasa memanfaatkan ikan tersebut untuk konsumsi karena mempunyai kandungan protein hewani yang tinggi. Permintaan pasar yang tinggi terhadap ikan uceng akan meningkatkan aktivitas penangkapan ikan uceng di sungai secara berlebihan. Salah satu langkah untuk menekan penurunan populasi ikan uceng adalah dengan cara budidaya. Penelitian ini bertujuan untuk mengetahui indeks gonadosomatik (IGS) serta struktur histologis ikan uceng (Nemacheilus fasciatus) jantan dan betina pada saat matang gonad dan pada saat belum matang gonad. Ikan uceng ditangkap dari sungai Kayangan, Pandawaharjo, Kulonprogo, Yogyakarta pada bulan Mei dan Agustus 2015. Spesimen tersebut kemudian ditimbang, dibedah dan diangkat gonadnya untuk mendapatkan nilai indeks gonadosomatik. Gonad difiksasi menggunakan Neutral Buffered Formaline untuk pembuatan sediaan histologis menggunakan Metode Paraffin dengan pewarnaan Hematoxylin Eosin. Analisis data struktur histologis gonad jantan dan betina dilakukan secara kualitatif (deskriptif komparatif). Analisis data Indeks Gonadosomatik dilakukan secara kuantitatif menggunakan Independent T-Test. indeks gonadosomatik ikan uceng jantan dan betina berbeda nyata, baik yang belum matang gonad maupun yang sudah matang gonad. Perbedaan komposisi fase perkembangan folikel terdapat pada ovarium ikan uceng yang belum matang dan yang sudah matang. Perbedaan komposisi sel-sel spermatogenik dapat diamati pada testis ikan uceng yang belum matang dan yang matang. Ikan uceng masih dimungkinkan untuk melakukan pemijahan di musim kemarau, akan tetapi hasilnya tidak akan memuaskan karena musim tersebut bukan merupakan periode puncak pemijahan untuk ikan uceng.
\end{abstract}

Kata kunci : Ikan uceng, Indeks Gonadosomatik, testis, ovarium

\section{Pendahuluan}

Salah satu ikan yang hidup di perairan tawar Indonesia adalah ikan uceng (Nemacheilus fasciatus). Masyarakat biasa memanfaatkan ikan uceng sebagai ikan konsumsi yang mempunyai kandungan protein hewani dan ada juga yang memelihara ikan uceng sebagai ikan hias dalam akuarium (Sinaga, 1995; Risyanto, et al., 2012). Ikan uceng termasuk ikan dengan nilai ekonomi yang tinggi (Suyitno, 2016). Ikan uceng digemari oleh masyarakat karena banyak mengandung asam lemak tak jenuh, tinggi kalori, dan juga mengandung DHA-EPA (Decosa Hexaenoat Acid
- Eicosa Pentaenoat Acid) yang sangat baik untuk kesehatan manusia (Supangat, 1995). Hal tersebut menyebabkan permintaan pasar untuk ikan uceng semakin meningkat. Pemenuhan permintaan ikan uceng sampai saat ini masih masih mengandalkan tangkapan langsung di alam (Prakoso et al., 2016). Permintaan pasar yang tinggi terhadap ikan uceng akan meningkatkan aktivitas penangkapan ikan uceng di sungai secara berlebihan. Salah satu langkah untuk menekan penurunan populasi ikan uceng di alam adalah dengan cara budidaya. 
Upaya konservasi dan budidaya ikan membutuhkan data aspek siklus hidup ikan termasuk kondisi lingkungan yang berkaitan dengan reproduksi ikan (Ismail et a I., 2016; Wakefield et al., 2011). Pada penelitian ini akan dilakukan pengamatan pada gonad ikan uceng yang belum matang dan gonad ikan uceng yang sudah matang dengan mengacu pada indeks gonadosomatik serta pengamatan pada struktur histologis gonad melalui preparat irisan. Dengan mengetahui indeks gonadosomatik dan struktur histologis gonad dapat diketahui waktu pemijahan, perkembangan gonad, dan fekunditas ikan. Hal tersebut nantinya dapat membantu upaya budidaya serta upaya konservasi dari ikan uceng. Penelitian bertujuan untuk mengetahui perbedaan indeks gonadosomatik (IGS) serta struktur histologis ikan uceng (Nemacheilus fasciatus) jantan dan betina pada saat matang gonad dan pada saat belum matang gonad.

\section{Metode}

\section{Materi Penelitian}

Spesimen yang digunakan pada penelitian ini adalah ikan uceng ( $N$. fasciatus) yang diambil dari sungai Kayangan, Pandawaharjo, Kulonprogo, Yogyakarta pada bulan Mei dan Agustus 2015. Bahan yang digunakan pada penelitian ini meliputi Neutral Buffered Formalin (NBF); air es; akuades; alkohol bertingkat; alkohol absolut; paraffin; Meyers albumin; toluol; xylol; larutan Hematoxylin Erlich; larutan Eosin 2\%; entelan; gelas benda; serta gelas penutup. Alat yang digunakan meliputi akuarium; alat bedah; baskom kecil; timbangan digital; timbangan analitik; botol flacon; botol timbang; set peralatan pembuatan sediaan histologis; mikroskop cahaya; dissecting mikroskop; kotak preparat; serta kamera digital.

\section{Cara Kerja}

Ikan uceng diambil dari sungai Kayangan, Pandawaharjo, Kulonprogo, Yogyakarta dengan menggunakan jala $3 \mathrm{~mm}$ dan jebakan bubu. Spesimen dibawa menggunakan akuarium kecil untuk diaklimatisasi dalam akuarium besar di Laboratorium Struktur dan Perkembangan Hewan, Fakultas Biologi, Universitas Gadjah Mada lengkap dengan set pompa filter air untuk proses selanjutnya. Spesimen dibius menggunakan air es kemudian ditimbang berat basahnya (Bbs). Ikan kemudian dibedah dan diambil gonad dan organ dalam yang lain. Berat tanpa organ dalam $\left(B_{t o}\right)$ dan berat gonadnya $\left(B_{g}\right)$ diukur menggunakan timbangan. Indeks gonadosomatik dihitung menggunakan rumus berikut :
$I G S=\frac{B_{g}}{B_{b s}} \times 100 \%$

Keterangan :

$\mathrm{B}_{\mathrm{g}} \quad$ : Berat gonad

$\mathrm{B}_{\mathrm{bs}} \quad$ : Berat basah (berat ikan keseluruhan)

(Howaida et al., 1998; Amtyaz et al., 2013)

Nilai indeks gonadosomatik (IGS) ikan uceng dibandingkan berdasarkan ukuran dan dianalisis menggunakan independent $T$ test untuk menunjukkan ada tidaknya beda nyata antara ikan yang sudah dan yang belum matang gonad.

Gonad yang telah diambil dimasukkan ke dalam larutan fiksatif NBF $5 \%$ untuk pembuatan sediaan histologis. Pembuatan sediaan histologis dilakukan menggunakan Metode Paraffin dan diwarnai menggunakan pewarnaan Hematoxylin Eosin (Disbrey \& Rack, 1970). Sediaan histologis gonad kemudian diamati menggunakan mikroskop cahaya kemudian didokumentasikan menggunakan kamera digital. Struktur histologis gonad ikan uceng yang belum matang dan yang sudah matang dianalisis secara deskriptif komparatif.

\section{Hasil dan Pembahasan}

Indeks gonadosomatik diartikan sebagai perbandingan antara berat gonad dengan berat somatik yang dinyatakan dalam persen (\%) (Picket and Pawson, 1994). Pengukuran indeks gonadosomatik dapat digunakan untuk menentukan stadium kematangan gonad, dengan melihat hubungan antara pertumbuhan somatik tubuh ikan dan perkembangan gonadnya, serta untuk memperkirakan waktu pemijahan (West, 1990; Wootton \& Smith, 2014).

Hasil penelitian ini menunjukkan bahwa rata-rata nilai indeks gonadosomatik ikan uceng (Nemacheilus fasciatus) jantan dan betina berbeda nyata, baik yang matang gonad maupun yang belum matang gonad (Tabel 1). Adanya beda nyata antara rata-rata nilai indeks gonadosomatik ikan uceng jantan dan ikan uceng betina dapat disebabkan karena adanya perbedaan periode kematangan gonad. Semakin meningkat tingkat kematangan gonad maka ovarium akan semakin membesar sehingga gonad akan semakin besar dan mencapai ukuran yang maksimal ketika ikan akan mengalami pemijahan (Effendi, 1997). Selain itu perbedaan tersebut dapat disebabkan karena struktur dan pertumbuhan gonad betina yang lebih besar dari pada gonad jantan pada ikan. Ovarium ikan uceng betina akan membesar secara maksimal, karena berisi telur, dan memenuhi seluruh rongga abdomen saat matang gonad. 
Tabel 1. Perbandingan rata-rata nilai indeks gonadosomatik (IGS) ikan uceng (Nemacheilus fasciatus) jantan dan betina pada saat gonad belum matang dan gonad sudah matang.

\begin{tabular}{|c|c|c|c|c|}
\hline \multirow{2}{*}{$\begin{array}{c}\text { Jenis } \\
\text { Kelamin }\end{array}$} & \multicolumn{2}{|c|}{$\mathbf{n}$} & \multirow{2}{*}{$\begin{array}{c}\text { Tahap } \\
\text { Perkembangan }\end{array}$} & \multirow{2}{*}{$\begin{array}{c}\text { Rerata IGS } \\
(\%)\end{array}$} \\
\hline & Mei & Agustus & & \\
\hline \multirow{2}{*}{ Betina } & 28 & 27 & Belum matang gonad & $1,96 \pm 1,84^{*}$ \\
\hline & 2 & 3 & Matang gonad & $20,53 \pm 10,05^{*}$ \\
\hline \multirow{2}{*}{ Jantan } & 9 & 8 & Belum matang gonad & $0,74 \pm 0,26^{*}$ \\
\hline & 1 & 2 & Matang gonad & $2,27 \pm 0,37^{*}$ \\
\hline
\end{tabular}

Hasil sampling dan pembedahan yang dilakukan pada bulan Mei dan Agustus menggambarkan rasio antara ikan betina dan ikan jantan $3: 1$. Hasil tersebut menunjukkan rasio yang berbeda dari penelitian Risyanto (2012) yang menunjukkan bahwa rasio jantan dan betina ikan uceng pada bulan Oktober sampai Desember adalah 1:1,25. Adanya perbedaan rasio kelamin ikan jantan dan betina pada ikan uceng tersebut dapat diakibatkan karena perbedaan bulan dan musim saat pengambilan ikan.

Perbedaan musim tentunya dapat berpengaruh pada berbagai aspek biologi ikan uceng. Bulan Mei-Agustus masuk dalam musim kemarau, sehingga dapat dikatakan bahwa ikan uceng tidak dalam kondisi yang ideal untuk reproduksi pada periode ini. Hal tersebut diperkuat oleh data pada Tabel 1 yang menunjukkan bahwa sangat sedikit ikan uceng yang matang gonad, baik jantan maupun betina, pada periode ini. Hanya 5 ekor ikan uceng betina yang tercatat matang gonad dari 60 ikan uceng yang berhasil disampling pada periode ini. Ikan uceng jantan bahkan hanya terhitung 3 ekor saja yang matang gonad dari 20 ekor. Proses kematangan gonad pada ikan dipengaruhi banyak faktor, yang salah satunya adalah proses fisiologi pada tubuh ikan. Musim tentunya akan sangat berpengaruh terhadap proses fisiologis pada tubuh ikan.

Penentuan periode pemijahan menggunakan tidak dapat hanya menggunakan Indeks gonadosomatik. Hal tersebut karenakan perkembangan kuantitatif gonad tidak sepenuhnya konsisten dengan gametogenesis (Barnett \& Pankhurst, 1999; Moulton \& Burton, 1999). Oleh karena itu observasi makroskopis dan histologis gonad juga perlu dipelajari untuk memberikan gambaran yang lebih akurat (Bromley, 2000; Macdonald et al., 2013) .

Hasil pengamatan secara makroskopik menunjukkan bahwa ovarium ikan uceng berjumlah sepasang dan memanjang, terletak di bagian lateral intestinum (Gambar 1). Ikan uceng memiliki ovarium bertipe cystovarian, dimana perkembangan folikel ovarium berada di dalam tunika albuginea (kista). Ovarium dalam keadaan matang gonad mengalami penambahan volume karena ovarium berisi telur dan yolk yang membuat dinding ovarium semakin meregang karena terdesak oleh telur yang tidak hanya berisi ratusan telur.

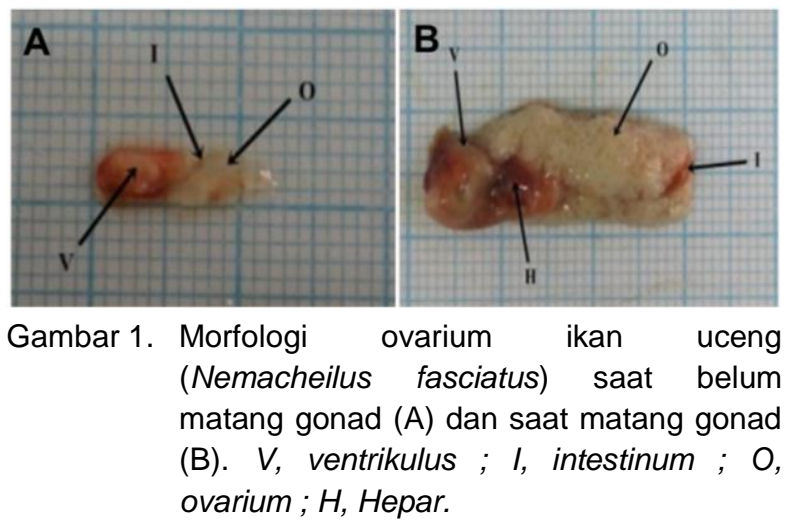

Struktur histologis gonad ikan uceng menunjukkan pola perkembangan oosit dalam satu ovarium menunjukkan adanya fase yang berbeda-beda pada waktu yang bersamaan, pola tersebut disebut dengan pola asinkronous (Blazer, 2002; Rahmawati, 2014).

Lima fase perkembangan dapat teramati pada ovarium ikan uceng (Tabel 2 dan Gambar 2) berdasarkan deskripsi Koc et al. (2008) dan Ismail et al. (2016). Kelima fase perkembangan tersebut antara lain adalah fase oosit primer, fase korteks alveoler; fase vitelogenik, fase oosit matang, dan fase oosit atretik.

1. Fase oosit primer

Beberapa nukleoli teramati pada fase ini di dalam nukleus (germinal vesicle) oosit. Diameter oosit berkisar antara 0,08 - 0,16 mm selama fase pertumbuhan pertama dalam fase oogenesis. Terdapat peningkatan proporsi antara fase pertumbuhan oosit dengan volume ovarium. Penebalan zona radiata di sekitar folikel tidak terjadi pada fase ini.

2. Fase korteks alveoler

Peningkatan struktur granular terjadi dalam ooplasma (sitoplasma oosit) dan penambahan ukuran folikel. Oosit menjadi lebih buram pada daerah yang mengelilingi inti. diameter oosit berkisar antara 0,16 mm - 0,28 mm. Inti membesar, zona radiata mulai terbentuk, dan sel epitel folikel mulai menebal. 


\section{Fase vitelogenik}

Ukuran oosit meningkat pada fase ini, yaitu berdiamater antara 0,28-0,74 $\mathrm{mm}$. Pada fase vitellogenik kortikal vesikel berbentuk sebuah bola yang berada di pinggir sitoplasma, jumlah dan ukuran yolk meningkat. Struktur granular yang muncul pada fase ini menjadi lebih besar dan bentuk intinya tidak teratur. Densitas vitelus meluas menuju pusat daerah cortical alveolar dan membran vitelin mulai berkembang.

4. Fase Oosit matang

Inti tidak dapat diamati pada fase ini karena struktur granular sudah mengisi seluruh sitoplasma. Diameter oosit mencapai 0,76 $0,78 \mathrm{~mm}$ yang merupakan ukuran maksimal oosit selama proses oogenesis. Membran inti larut sedangkan partikel lipid dan protein bergabung membentuk strutur yang homogen. Vesikel secara bertahap menjadi lebih besar, terdapat selubung vitelin. Sel-sel epitel folikel terlihat dengan inti sel yang seragam di luar membran.

5. Fase oosit atretik

Pada fase ini, struktur membran vitelin mulai hancur, vesikel menyatu secara menyeluruh. Terjadi resorpsi yolk dan hancurnya selubung vitelin.

Tipe perkembangan oosit ikan uceng adalah tipe asinkronous. Hal tersebut ditunjukkan oleh struktur ovarium yang terdapat lima fase perkembangan folikel, baik ketika ovarium tersebut matang maupun belum matang, walaupun komposisi antara folikel satu dengan folikel yang lain berbeda-beda. Ovarium yang telah matang akan memiliki prosentase fase vitelogenik dan fase oosit matang lebih banyak dibandingkan fase pertumbuhan folikel yang lain. Penjelasan tersebut menunjukkan bahwa ikan uceng memiliki potensi untuk melakukan pemijahan sepanjang tahun akan tetapi puncak periode pemijahan tidak terjadi pada musim kemarau.

Tabel 2. Komposisi folikel ovarium saat belum matang gonad dan saat matang gonad

\begin{tabular}{ccc}
\hline $\begin{array}{c}\text { Tahapan } \\
\text { Perkembangan }\end{array}$ & $\begin{array}{c}\text { Belum } \\
\text { matang } \\
\text { gonad }\end{array}$ & $\begin{array}{c}\text { Matang } \\
\text { Gonad }\end{array}$ \\
\hline Oosit primer & +++ & +++ \\
Cortical alveolar & - & ++ \\
Vitelogenik & - & ++ \\
Oosit matang & - & +++ \\
Oosit atresia & + & - \\
\hline
\end{tabular}

\section{Keterangan :}

$+++=$ ditemukan pada setiap bidang pandang

$++\quad=$ ditemukan pada 3 - 4 bidang pandang

$+\quad=$ ditemukan hanya pada 1-2 bidang pandang

= tidak ditemukan pada setiap bidang pandang
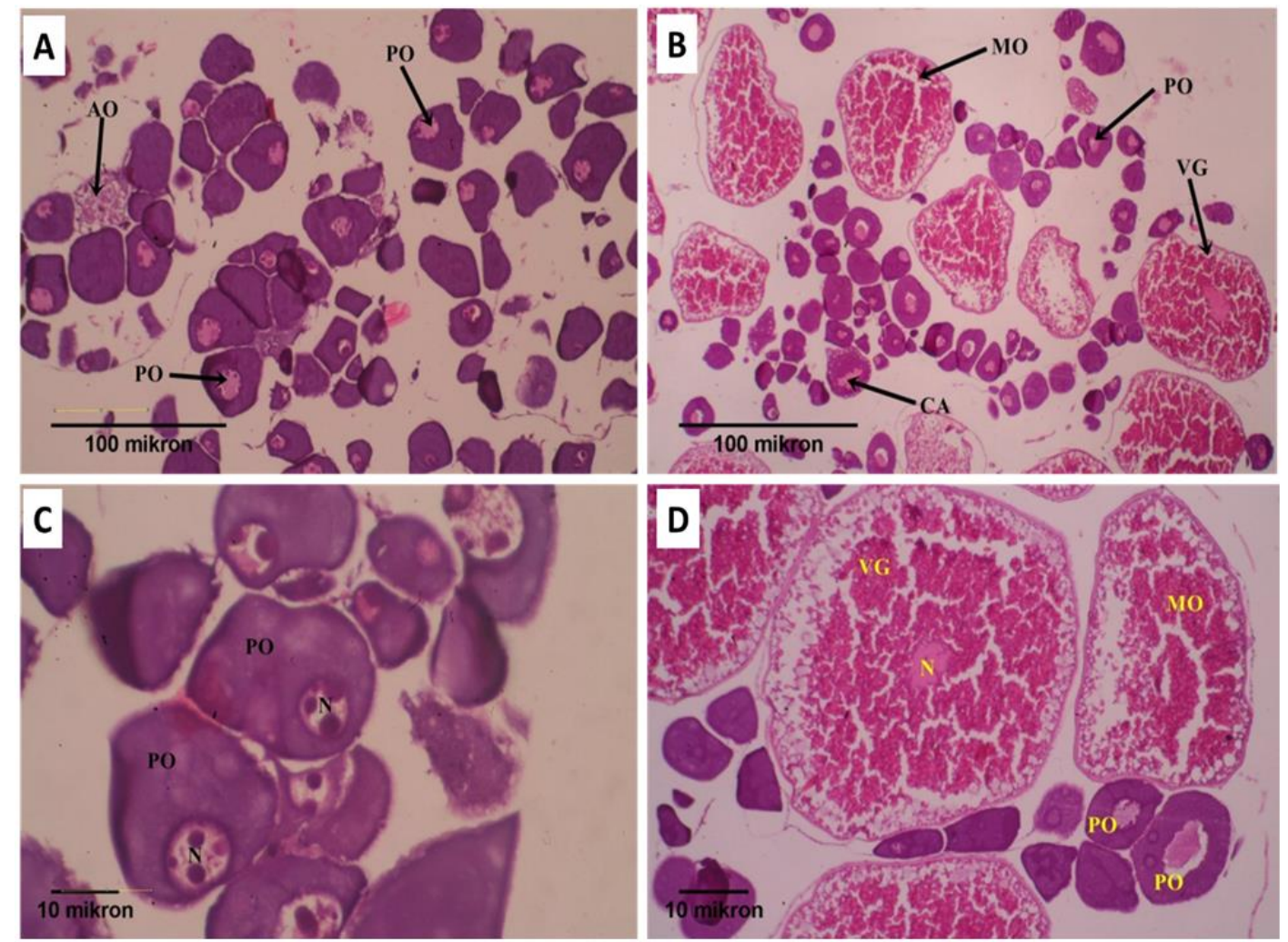

Gambar 2. Struktur Histologis ovarium ikan uceng (Nemacheilus fasciatus) saat gonad belum matang (A\&C) dan gonad sudah matang (B\&D) pada perbesaran 10x10 (A\&B) dan 40×10 (C\&D). PO, Primary Oosit ; $A O$, Atresia Oosit ; N, nukleus ; MO, mature oosit ; CA, cortical alveolar ; VG, vitellogenik. 
Hasil pengamatan pada ikan jantan secara makroskopik menunjukkan bahwa testis ikan uceng terletak di caudal ventriculus, berjumlah sepasang, berbentuk membulat dan berada di lateral intestinum (Gambar 3). Lapisan terluar testis berupa tunika albuginea, yang menggantungkan testis pada rongga abdomen. Menurut Takhasima dan Hibiya (1995), gonad jantan pada ikan terdiri dari sepasang testis, vesicular seminalis, serta saluran sperma. Secara makroskopis, testis dalam keadaan matang gonad berukuran lebih besar, berwarna putih susu, berbentuk membulat, dan lebih kompak, sedangkan testis dalam keadaan tidak matang gonad berukuran lebih kecil, berwarna putih, dan berbentuk memanjang (Gambar 3).

Terdapat dua macam testis, yaitu tipe tubular dan tipe lobular. Testis tipe tubular adalah testis yang dibagian tengahnya terdapat rongga tempat penyimpanan spermatozoa yang disatukan dalam suatu berkas yang bernama spermatozeugmas, sedangkan testis bertipe lobular adalah testis yang memiliki jaringan ikat fibrosa yang berasal dari kapsula testis membentuk struktur lobuli yang dilapisi oleh sel sertoli. Di dalam lobuli tersebut, spermatogonium mengalami pembelahan secara mitosis sehingga menghasilkan kista spermatogonium (Billard, 1986 ; Diana, 2007). Menurut Parenti \& Grier (2004) kebanyakan ikan anggota Familia Cyprinidae, termasuk ikan uceng, mempunyai testis bertipe tubular beranastomosa. Testis bertipe tubular beranastomosa adalah tubulus testis tidak langsung berujung keluar namun diantara tubulus-tubulus tersebut saling berhubungan dan membentuk jaring-jaring (anastomosa) sebelum nantinya bersatu membentuk saluran yang akan bermuara keluar pada bagian caudal (Rahmawati, 2014).

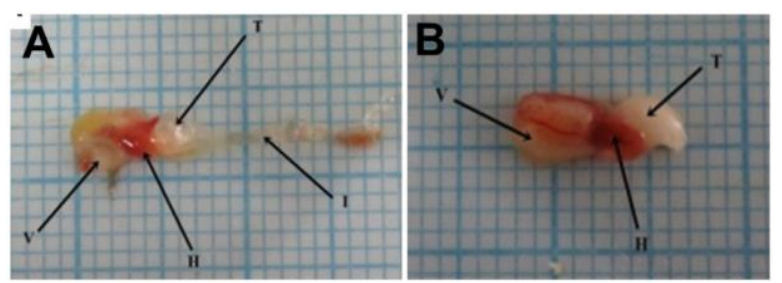

Gambar 3. Morfologi testis ikan uceng (Nemacheilus fasciatus) pada saat gonad belum matang (A) dan gonad sudah matang (B). $V$, ventrikulus ; I, intestinum ; $T$, testis ; $H$, Hepar.

Hasil pengamatan yang dilakukan pada irisan membujur preparat testis ikan uceng (Gambar 4), menunjukkan bahwa batas antar tubulus seminiferus tidak terlihat dengan jelas namun masih berhubungan satu sama lain. Berdasarkan pengamatan yang telah dilakukan pada preparat gonad ikan uceng dapat diketahui bahwa perkembangan sel-sel spermatogenik pada testis ikan uceng meliputi spermatogonium, spermatosit primer, spermatosit sekunder, serta spermatid dan spermatozoa.

1. Spermatogonium

Spermatogonium merupakan sel induk yang terletak di dekat membrana basalis, granula berwarna terang, dan sebuah nukleolus. Spermatogonium melalui berbagai fase pembelahan mitosis sehingga memiliki struktur yang bervariasi pada dinding tubulus seminiferus. Spermatogonium bersifat basofilik dengan inti pucat. Spermatogonium nantinya akan membelah menjadi spermatosit primer.

2. Spermatosit primer

Spermatosit primer mempunyai sel berukuran besar dengan inti sel bulat besar dan bersifat basofilik. Setiap spermatosit primer selanjutnya akan melakukan mekanisme pembelahan secara meiosis untuk menghasilkan dua spermatosit sekunder.

3. Spermatosit sekunder

Pada spermatosit sekunder jumlah kromosom menjadi setengah dari spermatosit primer. Ukuran sel pada spermatosit sekunder setengah kali lebih kecil dari ukuran spermatosit primer dengan kromosom haploid.

4. Spermatid dan spermatozoa

Spermatid merupakan hasil pembelahan secara meiosis dari spermatosit sekunder dan memiliki sel berbentuk oval. Spermatid nantinya akan berdiferensiasi menjadi spermatozoa dengan adanya pembentukan flagella dan orientasi organ sebelum nantinya dilepaskan keluar tubuh

Berdasarkan hasil pengamatan pada testis ikan uceng dalam keadaan matang gonad dan testis ikan uceng dalam keadaan tidak matang gonad terjadi perbedaan komposisi sel-sel spermatogenik penyusunnya. Menurut penelitian yang dilakukan oleh Rahmawati (2014) pada ikan wader pari $(R$. lateristriata), testis dalam keadaan belum matang gonad mempunyai lebih banyak mengandung kista spermatogonium dalam testisnya, sedangkan testis dalam keadaan sudah matang gonad akan terdapat banyak sel spermatosit sekunder dan spermatid dalam testisnya sedangkan komposisi kista spermatogonium lebih sedikit. Hal tersebut juga terjadi pada pengamatan struktur histologis testis ikan uceng dimana testis ikan uceng dalam keadaan matang gonad mempunyai komposisi kista spermatogonium yang lebih banyak dari 
testis dalam keadaan matang gonad, namun testis dalam keadaan belum matang gonad mempunyai komposisi spermatozoa lebih sedikit dibanding testis dalam keadaan matang gonad. Sebaliknya pada testis dalam keadaan matang gonad memiliki spermatozoa yang lebih banyak dari pada testis dalam keadaan belum matang gonad dan memiliki kista spermatogonium yang jauh lebih sedikit dibanding testis yang belum matang gonad.
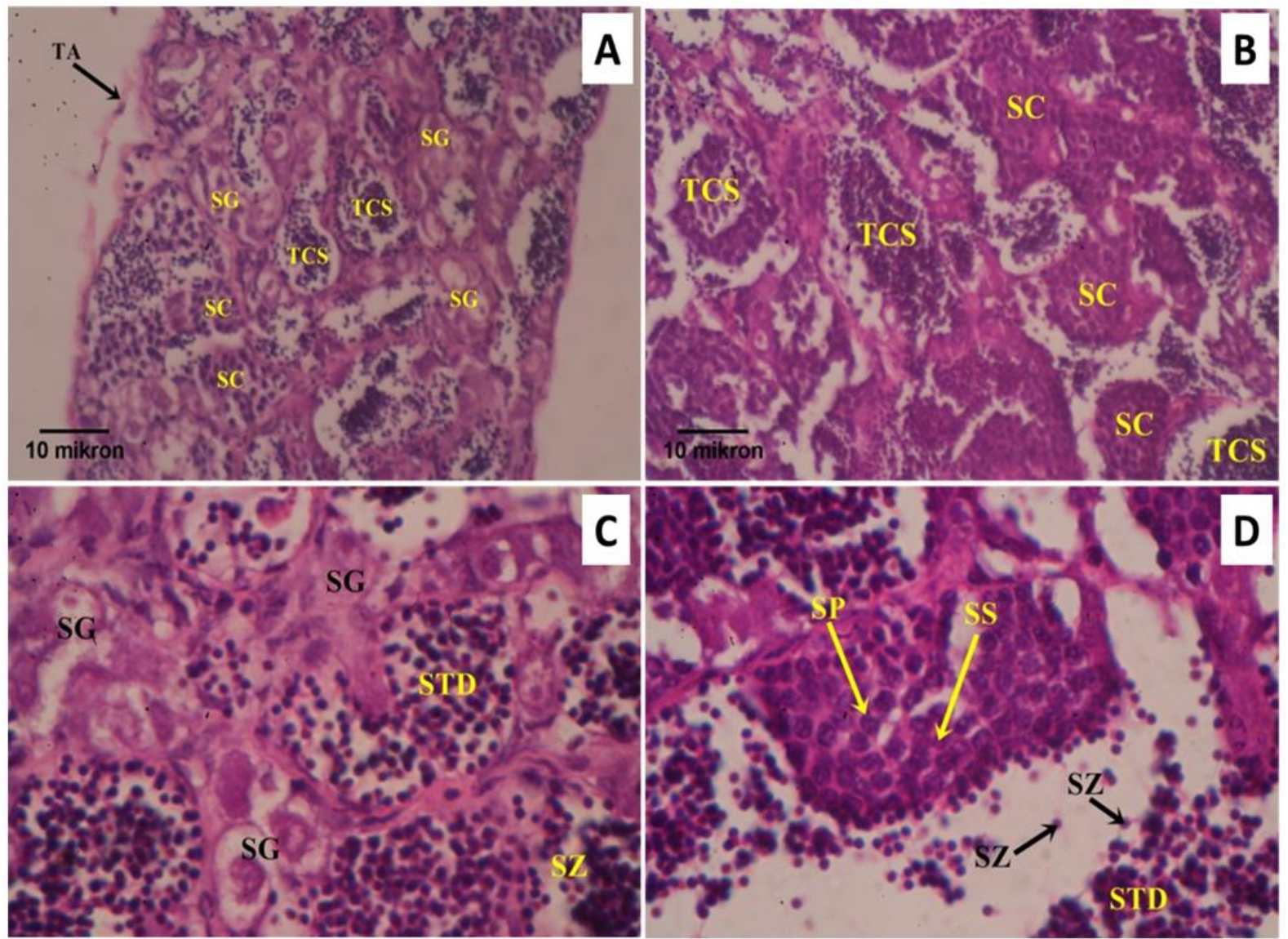

Gambar 4. Struktur Histologis testis ikan uceng (Nemacheilus fasciatus) pada saat gonad belum matang (A\&C) dan

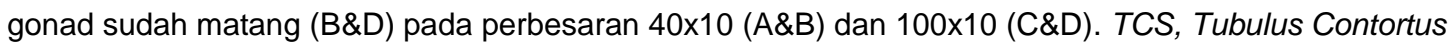
Seminiferus ; SC, Spermatogenic cell ; SG, Spermatogonium ; STD, spermatid ; SP, spermatosit primer ; SS, spermatosit sekunder ; SZ, spermatozoa.

\section{Simpulan}

Berdasarkan penelitian yang telah dilakukan, dapat disimpulkan bahwa indeks gonadosomatik ikan uceng jantan dan betina berbeda nyata, baik yang belum matang gonad maupun yang sudah matang gonad. Perbedaan komposisi fase perkembangan folikel terdapat pada ovarium ikan uceng yang belum matang gonad dan yang sudah matang gonad. Perbedaan komposisi sel-sel spermatogenik dapat diamati pada testis ikan uceng yang belum matang gonad dan yang matang gonad. Ikan uceng masih dimungkinkan untuk melakukan pemijahan di

\section{Daftar Referensi}

Barnett, C.W., Pankhurst, N.W., 1999. Reproductive biology and endocrinology of green back flounder Rhombosole musim kemarau, akan tetapi hasilnya tidak akan memuaskan karena musim tersebut bukan merupakan periode puncak pemijahan untuk ikan uceng.

\section{Ucapan Terima Kasih}

Penelitian ini merupakan bagian dari penelitian yang didanai oleh Hibah Penelitian Dosen Muda Tahun Anggaran 2015 yang diselenggarakan oleh Lembaga Penelitian dan Pengabdian Masyarakat (LPPM) Universitas Gadjah Mada.

tapirina (Günther 1862). Mar. Freshwater Res. 50, 35-42.

Billard, R., 1986. Spermatogenesis and Spermatology of some Teleost Fish 
Species. J. Reproduction Nutrition Development, (26) : 878-880.

Blazer, V.S. 2002. Histophatological assesment of gonadal tissue in wild fishes. Fish Physiology and Biochemistry. 26: 85101.

Bromley, P.J., 2000. Growth, sexual maturation and spawning in central North SeaPlaice (Pleuronectes platessa L.), and the generation of maturity ogives fromcommercial catch data. J. Sea Res, $44,27-43$.

Diana, E., 2007. Skripsi : Tingkat Kematangan Gonad Ikan Wader (Rasbora argyrotaenia) di Sekitar Mata Air Ponggok Klaten, Jawa Tengah. Fakultas Matematika dan IImu Pengetahuan Alam Universitas Sebelas Maret. Surakarta. Hal. 10-15.

Disbrey, B. D. and Rack, J. H. 1970. Histological Laboratory Methods. E. \& S. Livingstone, Edinburg. pp. 56-128.

Effendi, M.I. 1997. Biologi Perikanan. Yayasan Pustaka Nusatama. Yogyakarta, Hal. 154-156.

Ismail, R.F., Assem, S.S. , Fahmy, A.F., Abou Shabana, N.M., El-Sayed, H.S.,AlAbsawey, M.A., 2016. Reproductive biology, steroid and biochemical profiles of Dentex dentex ovaries in the Eastern Mediterranean in relation to histological structure. Egyptian Journal of Aquatic Research, 42, 149-160.

Koc, N.D, Aytekin, Y., and Yuce, R., 2008. Ovary Maturation Stages and Histological Investigation of Ovary of the Zebrafish (Danio rerio). J. Biology and Technology (51) : $515-519$.

Macdonald, P., Angus (née Laurenson), C.H., Marshall, C.T., 2013. Spatial variation inlife history characteristics of common megrim (Lepidorhombus whiffiagonis) onthe Northern Shelf. J. Sea Res. 75, 62-68.

Moulton, S.M., Burton, M.P.M., 1999. Histological observations on spermatogene-sis in winter flounder, Pleuronectes americanus Walbaum, from Conception Bay,Newfoundland, Canada. Can. J. Zool. 77, 1682-1689.

Parenti, L.R. and Grier. H.J., 2004. Evolution and phylogeny of gonad morphology in bony fishes. Inter. Comp. Biol, 44 : 333-348

Penyuluhan Kelautan dan Perikanan. 2015. Kajian dan Tantangan Budidaya Ikan Uceng dalam Rangka Konservasi Ikan
Spesifik Lokal Kabupaten Temanggung. www.pusluh.kkp.go.id/mfce/html. Diakses tanggal 2 Januari 2016.

Picket, G.D. and Pawson, M.G., 1994. Sea Bass : Biology, Axploitation, and Conservation. Chapman and Hall. London. p.136

Prakoso, V.A., Ath-thar, M.H.F., Subagja, J., dan Kristanto, A.H., 2016. Pertumbuhan ikan uceng (Nemacheilus fasciatus) dengan padat tebar berbeda dalam lingkungan ex situ. Jurnal Riset Akuakultur, 11 (4), hal. 355-362

Rahmawati, S. 2014. Indeks Gonadosomatik dan Struktur Histologis Gonad Ikan Wader Pari (Rasbora lateristriata Bleeker, 1854) pada Tahap Perkembangan Pra Dewasa dan Dewasa. Skripsi. Fakultas Biologi Universitas Gadjah Mada. Yogyakarta. Hal 21-25.

Risyanto, S., Sulistio, I., dan Ardli, E.R., 2012. Ekologi Ikan Uceng (Nemacheilus fasciatus) di Sungai Banjaran Kabupaten Banyumas. Prosiding Seminar Nasional : Biodiversitas dan Bioteknologi Sumberdaya Akuatik. Hal. 824.

Sinaga, T.P. 1995. Bioekologi Komunitas Ikan di Sungai Banjaran Kab. Banyumas Jawa Tengah. Tesis Program Pasca Sarjana Institut Pertanian Bogor, Bogor.

Supangat. 1995. Studi Analisis Isi Lambung, Sifat Pertumbuhan, Fekunditas, Indeks kematangan Gonad dan Rasio Kelamin Ikan Uceng di Sungai Logawa Purwokerto Kabupaten Banyumas. Skripsi Fakultas Biologi Universitas Jendral Soedirman. Purwokerto.

Suyitno, H. 2016. Mencoba Kembangkan Ikan Uceng di Luar Habitatnya. http://jateng.antaranews.com/detail/men coba-kembangkan-ikan-uceng-di-luarhabitatnya.html. Akses tanggal 2 Januari 2017.

Takashima, F. and T. Hibiya. 1995. Gonad. In: an Atlas of Fish Histology Normal and Pathological Features. 2nd Edited by Fumio Takhasima and T. Hibiya Kodansu, Ltd. Tokyo. pp : 128-153.

Tang, U. M. dan R. Affandi. 2004. Biologi Reproduksi lkan. UNRI Press. Riau.

Wakefield, C.B., Fairclough, D.V., Lenanton, R.C.J., Potter, I.C., 2011. Spawn-ing and nursery habitat partitioning and movement patterns of Pagrusauratus (Sparidae) on the lower west coast of Australia. Fish. Res. 109, 243-251. 
West, G., 1990. Methods of assessing ovarian development in fishes: a review. Aust.J. Mar. Freshwater Res 41, 199-222.

Wootton, R.J., Smith, C., 2014. Gametogenesis. In: Wootton, R.J., Smith, C. (Eds.), Reproductive Biology of Teleost Fishes.
John Wiley \& Sons, Ltd, Chichester, UK, pp. 45-80.

Sharon, G and D. Zilberg. 2015. Atlas of Fish Histology and Histopathology. JCA Charitable Foundation. P. 32. 